\title{
Open
}

\section{The Modulatory Role of the Lateral Septum on Neuroendocrine and Behavioral Stress Responses}

\author{
Georg M Singewald', Alesja Rjabokon', Nicolas Singewald' and Karl Ebner*,I \\ 'Department of Pharmacology and Toxicology, Institute of Pharmacy and Center for Molecular Biosciences Innsbruck (CMBI), \\ Leopold-Franzens-University of Innsbruck, Innsbruck, Austria
}

\begin{abstract}
The lateral septum (LS) has been shown to have a key role in emotional processes and stress responses. However, the exact role of the LS on stress modulation is not clear, as previous lesion studies mostly used electrolytic lesions, thereby destroying the whole septal area, including medial components and/or fibers of passage. The aim of the present study was therefore, to investigate the effects of selective excitotoxic ablation of the LS on neuroendocrine and behavioral stress responses in rats. Bilateral ibotenic acid lesions of the LS increased hypothalamo-pituitary-adrenocortical (HPA) axis responses to forced swim stress indicated by enhanced plasma ACTH and corticosterone responses and higher stress-induced c-Fos-like immunoreactivity in the paraventricular hypothalamic nucleus. Moreover, LS-lesioned animals showed a more passive coping style in the forced swim test indicated by increased floating and reduced struggling/ swimming behavior compared with sham-lesioned controls. Interestingly, intraseptal corticosteroid receptor blockade modulated behavioral stress coping but failed to change HPA axis stress responses. Further experiments aimed at elucidating underlying neurochemical mechanisms revealed that intraseptal administration of the selective 5-HTIA receptor antagonist WAY-I 00635 increased and prolonged stress-induced ACTH and corticosterone levels mimicking lesion effects, while the agonist 8-OH-DPAT suppressed HPA axis activity facilitating the inhibitory role of the LS. In addition, 8-OH-DPAT-injected animals showed increased active and decreased passive coping strategies during forced swimming suggesting antidepressant efficacy. Taken together, our data suggest that the LS promotes active stress coping behavior and is involved in a HPA-inhibitory mechanism that is at least in part mediated by septal 5 - $\mathrm{HT}_{\text {IA }}$ receptors and does not involve a glucocorticoid mediated feedback mechanism.
\end{abstract}

Neuropsychopharmacology (20II) 36, 793-804; doi:I0.1038/npp.20 10.213; published online I5 December 2010

Keywords: forced swimming; HPA axis; ACTH; corticosterone; glucocorticoids; serotonin

\section{INTRODUCTION}

Considerable evidence suggests that a significant element in the etiology of numerous psychiatric disorders, including depression and post-traumatic stress disorder, is a dysregulated stress hormone function (De Kloet et al, 2005; Krishnan and Nestler, 2008). The release of stress hormones, such as glucocorticoids, is regulated mainly by the hypothalamo-pituitary-adrenocortical (HPA) axis, and it is well documented that glucocorticoids have an important role in the adaptation of the organism to stress, including the coordination of appropriate behavioral response to stressors (McEwen, 2007). The importance of maintaining glucocorticoid secretion within tolerable limits

\footnotetext{
*Correspondence: Dr K Ebner, Leopold-Franzens-University of Innsbruck, Department of Pharmacology and Toxicology, Peter MayrStreet I, Innsbruck A-6020, Austria, Tel: + 43512507 5623, Fax: + 435 I2-507-2760, E-mail: karl.ebner@uibk.ac.at

Received 8 June 2010; revised 21 September 2010; accepted 4 November 2010
}

requires efficient mechanisms for inhibiting neuroendocrine stress responses. To avoid excessive stress reactions glucocorticoid levels are regulated by a negative feedback mechanism, which mainly acts at the level of hypothalamus and pituitary (Keller-Wood and Dallman, 1984; De Kloet et al, 1998). In parallel with steroid feedback, there is also evidence for the existence of further glucocorticoidindependent inhibitory pathways that might emanate from neuronal sources including GABAergic neurons from multiple brain areas including neurons scattered in the immediate surroundings of the hypothalamic paraventricular nucleus (PVN; Herman et al, 2003, 2004, 2005; Cullinan et al, 2008). Additional studies have now provided evidence that the lateral septum (LS) is involved in the HPA axis activity modulation (Herman et al, 1996, 2005). However, the exact role of the LS in HPA axis regulation is presently obscure, because of inconsistent findings from previous studies. For example, basal plasma corticosterone levels following septal lesions are elevated in some studies (Usher et al, 1974; Dobrakovova et al, 1982) but not in others (Seggie and Brown, 1971; Seggie et al, 1974; Uhlir 
et al, 1974; Dobrakovova et al, 1982; Seggie, 1987). Moreover, the impact of LS neurons on the expression of anxiety-related behaviors are similar controversial as both reduced (Pesold and Treit, 1992; Menard and Treit, 1996) as well as increased anxiety levels (Albert and Chew, 1980; Yadin et al, 1993) were found after septal lesions. These discrepant findings might be related to the fact that most of the above mentioned lesion studies used large electrolytic lesions, thereby damaging both lateral and medial divisions of the septal area as well as extensive portions of the fornix system and thus fibers passing through this region. So far, only one study investigated the effects of selective LS lesions on the HPA axis activity by using the excitotoxic lesion agent ibotenic acid, that spares fibers of passage (Herman et al, 1996). However, as this study was conducted under basal conditions only, wherein no modulatory function of the LS was found, the specific role of LS neurons under stress conditions is still unknown.

The aim of the present study was to investigate the effects of axon-sparing excitotoxic lesions of LS neurons on neuroendocrine and behavioral stress responses. Moreover, we examined whether the LS is involved in the glucocorticoidmediated negative feedback mechanism, as a high density of glucocorticoid receptors was found in the LS of rodents and primates (Morimoto et al, 1996; Patel et al, 2000). Finally, we aimed to study the underlying neurochemical mechanisms of how LS neurons modulate neuroendocrine and behavioral stress responses.

\section{MATERIALS AND METHODS}

\section{Animals}

All experiments were carried out on adult male SpragueDawley rats (250-320 g). Before use, the animals were housed in groups of four to six under controlled laboratory conditions $(12: 12 \mathrm{~h}$ light/dark cycle with lights on at 0700 , $21 \pm 1{ }^{\circ} \mathrm{C}, 60 \%$ humidity, pelleted food and water ad libitum) for at least 1 week after delivery from the supplier. All experiments were approved by the local Ethics Committee on Animal Care and Use of the Austrian governmental body.

\section{Surgery}

All surgeries were performed under sodium pentobarbital $(40 \mathrm{mg} / \mathrm{kg}$, i.p. $)$ and ketamine $(50 \mathrm{mg} / \mathrm{kg}$, i.p. $)$ anesthesia. Moreover, before incision the local anesthetic xylocaine (AstraZeneca, Vienna, Austria) were injected on the head surface of animals. Postoperatively, rats received a one-time injection of buprenorphine $(0.03 \mathrm{mg} / \mathrm{kg}$ i.m.).

Excitotoxic lesions. Excitotoxic lesions were produced bilaterally by microinjections of ibotenic acid (SigmaAldrich, Steinheim, Germany) into the LS with a Hamilton microsyringe stereotaxically inserted according to a brain atlas (Paxinos and Watson, 1998). The implantation coordinates were: $0.6 \mathrm{~mm}$ rostral to bregma, $0.8 \mathrm{~mm}$ lateral to the midline. To ensure ablation that implies most of the LS, lesions were placed 7.0 and $5.5 \mathrm{~mm}$ ventral to skull surface. Each injecting point was infused with $0.5 \mu \mathrm{l}$ of ibotenic acid $(5 \mu \mathrm{g} / \mu \mathrm{l})$ during a time period of $5 \mathrm{~min}$. After injections the injection cannula was left in position for an additional 5 min to facilitate drug diffusion and minimize dragging of the injected liquid along the injection tract. The sham-lesioned animals received the same surgical treatment as a burr hole was drilled in the skull, and the dura was removed in the location dorsal to LS lesion placements, except that no ibotenic acid was applied.

Implantation of microinjection cannulae. For microinjection experiments, 25 gauge stainless steel cannulae $(15 \mathrm{~mm}$ length) used as guide cannulae were bilaterally implanted with their tip $2 \mathrm{~mm}$ above the LS (implantation coordinates: $0.6 \mathrm{~mm}$ rostral to bregma, $1.6 \mathrm{~mm}$ lateral to the midline, $3.7 \mathrm{~mm}$ below the surface of the skull with an angle of $10^{\circ}$ to avoid sagittal sinus damage) and fixed to the skull with two jeweler's screws and dental cement.

Implantation of a microdialysis probe. A homemade, U-shaped microdialysis probe was stereotaxically implanted 2 days prior to experiments as previously described (Ebner et al, 2004) with its tip reaching the right LS (implantation coordinates: $0.6 \mathrm{~mm}$ rostral to bregma, $1.6 \mathrm{~mm}$ lateral to the midline, $7.0 \mathrm{~mm}$ below the surface of the skull with an angle of $10^{\circ}$ to avoid sagittal sinus damage). The probe consisting of an $18 \mathrm{kDa}$ dialysis membrane (Hemophan, Membrana, Wuppertal, Germany) with an active surface length of $2 \mathrm{~mm}$ was fixed to the skull with two jeweler's screws and dental cement. The two endings of the probe were attached to $5-\mathrm{cm}$ long pieces of polyethylene tubing for connection with the infusion pump.

Implantation of a jugular venous catheter. A silastictipped vinyl catheter was inserted into the left jugular vein, routed under the skin and exteriorized at the neck of the animal as described previously (Ebner et al, 2005). The wounds were closed using metal clips. The catheter was filled with sterile saline containing gentamycin (30.000 IU/rat, Centravet, Bad Bentheim, Germany) and flushed with the same solution 2 days after surgery. On the day of the experiment the catheters were connected to $1-\mathrm{ml}$ plastic syringes via $\sim 40-\mathrm{cm}$ long pieces of PE-50 tubing $2 \mathrm{~h}$ before starting the experiment. Blood sampling through a preimplanted jugular vein catheter allows repeated blood sampling from conscious, freely moving rats without restraining animals.

\section{Experimental protocol}

After surgery, rats were housed individually in transparent plexiglas cages until testing. Operated animals were allowed to recover from surgery for 2-3 days, during which they were handled for $3 \mathrm{~min}$ twice daily to familiarize them with the experimental procedure and to minimize nonspecific stress responses during the experiments. At least $16 \mathrm{~h}$ before experiments, animals were placed in the experimental room and allowed to habituate. All experiments were performed between 0700 and 1600 . Exposure to the stressor was always completed between 1100 and 1400 hours to minimize circadian rhythm-related variations in stress responses. 
Effects of LS lesions on stress responses. The experiment started with the collection of a first blood sample $(0.3 \mathrm{ml})$ under basal conditions, $30 \mathrm{~min}$ prior to stress exposure. After sampling of the basal blood sample, lesioned and sham-lesioned animals were exposed to forced swimming according to the procedure described previously (Ebner et al, 2008). Briefly, the rats were forced to swim for $5 \mathrm{~min}$ in a square plastic tank ( $40 \mathrm{~cm}$ in diameter) filled to a depth of $30 \mathrm{~cm}$ with tap water $\left(20 \pm 1^{\circ} \mathrm{C}\right)$. During the forced swimming session, the behavior was recorded by a video system and scored by a trained observer blind to the treatment of animals, quantifying absolute time measurements. The behavior of the animals was assigned to one of the three following behavioral categories: (1) struggling, defined as movements during which the forelimbs broke the surface of water; (2) swimming, defined as movement of the animal induced by movements of the fore and hind limbs without breaking the water surface; and (3) floating defined as the behavior during which the animal used limb movement just to keep its equilibrium without any movement of the trunk (Ebner et al, 2008). After the 5-min swimming session, animals were gently dried using a towel and returned to their home cage. To determine the time course of plasma ACTH and corticosterone release in response to forced swim stress, additional blood samples were collected 10,30, and $60 \mathrm{~min}$ after onset of the stressor. Sampled blood volumes were immediately replaced with an equal volume of heparinized saline.

Effects of intraseptal administration of selective corticosteroid receptor antagonists on stress responses. In a separate group of animals, the stylets of guide cannulae were replaced by microinjection cannulae (31 gauge), which were $2 \mathrm{~mm}$ longer than the guide cannulae, thus reaching the LS. Injection cannulae were connected to a syringe mounted on a microinfusion pump (TSE-Systems, Bad Homburg, Germany) and filled either with artificial cerebrospinal fluid (aCSF; $\mathrm{pH} 7.2 ; 140 \mathrm{mM} \mathrm{NaCl}, 3.0 \mathrm{mM}$ $\mathrm{KCl}, 1.25 \mathrm{mM} \mathrm{CaCl}_{2}, 1.0 \mathrm{mM} \mathrm{MgCl}_{2}, 1.2 \mathrm{mM} \mathrm{Na} \mathrm{NPO}_{4}$, $0.3 \mathrm{mM} \mathrm{NaH}_{2} \mathrm{PO}_{4}$, and $3.0 \mathrm{mM}$ glucose) or aCSF containing the corticosteroid receptor antagonists mifepristone or RU-28318 (30 and $150 \mu \mathrm{M}$; Tocris Bioscience, Bristol, UK). The dose range of RU-28318 and mifepristone used in our experiments was based on previous studies demonstrating a modulatory effect on HPA axis activity as well as emotional behavior in rats after intracerebroventricular, intrahippocampal, or intraseptal injections (Ratka et al, 1989; Korte et al, 1995; Van Haarst et al, 1997; Calvo and Volosin, 2001; Gesing et al, 2001; Calfa et al, 2006). After a habituation period of $60 \mathrm{~min}$, experiment started with the collection of two blood samples $(0.3 \mathrm{ml})$ under basal conditions, 30 and $15 \mathrm{~min}$ before stress exposure. Bilateral infusions of the corticosteroid receptor antagonists into the LS started $12 \mathrm{~min}$ before onset of the stressor. The injection time of $7.5 \mathrm{~min}$ with a defined flow rate of $0.2 \mu \mathrm{l} / \mathrm{min}$ achieved a total volume of $1.5 \mu \mathrm{l}$ ( $=20$ and $100 \mathrm{ng}$ ) for each injection side followed by $2.5 \mathrm{~min}$, wherein the injectors were kept in place to allow absorption of the injection bolus into the tissue. After injections, another blood sample was taken and 1 min later animals were exposed to the forced swimming procedure for $5 \mathrm{~min}$ as described above. During the swim session behavioral output was scored and analyzed as described above. Additional blood samples were collected 10,30 , and $60 \mathrm{~min}$ after onset of the stressor and again equal volume of heparinized saline was reinfused.

Effects of intraseptal administration of $5-\mathrm{HT}_{1 \mathrm{~A}}$ receptor ligands on stress responses. In a further series of experiments, the selective $5-\mathrm{HT}_{1 \mathrm{~A}}$ receptor agonist $8-\mathrm{OH}-\mathrm{DPAT}$ (10 $\mathrm{g}$ /side; Sigma-Aldrich, Steinheim, Germany) was bilaterally microinjected into the LS as described above. To intraseptally administer the selective $5-\mathrm{HT}_{1 \mathrm{~A}}$ receptor antagonist WAY-100635 (Sigma-Aldrich) over an extended period of time with no further perturbation to the surrounding tissue (Bourne, 2003), we decided to infuse the compound via retrodialysis into the LS as described previously (Ebner et al, 2008). Briefly, at the day of experiment the microdialysis probe was connected to a syringe mounted onto a superfusion pump and dialyzed with aCSF. After an equilibration period of $120 \mathrm{~min}$, experiment started with the collection of two blood samples $(0.3 \mathrm{ml})$ under basal conditions, 120 and $60 \mathrm{~min}$ before stress exposure, followed by infusion of WAY$100635(10 \mu \mathrm{M})$ in aCSF or aCSF alone (controls) with a flow rate of $3.3 \mu \mathrm{l} / \mathrm{min}$. At $30 \mathrm{~min}$ after the start of retrodialysis, another blood sample was collected. The drug reached the LS after $\sim 5-6 \mathrm{~min}$ and forced swimming was applied $30 \mathrm{~min}$ later as described above. During the swim session, behavioral output was scored and analyzed as described above, and afterwards three additional blood samples were collected at 10,30 , and $60 \mathrm{~min}$ (sample 4-6) after onset of the stressor.

\section{ACTH and corticosterone radioimmunoassay}

Plasma ACTH and corticosterone concentrations were measured by radioimmunoassay using commercially available kits (MP Biomedicals, Orangeburg, NY, USA) with an intra- and inter-assay variability of $<10 \%$, and a lower limit of detection of $6 \mathrm{pg} / \mathrm{ml}$ for ACTH and $8 \mathrm{ng} / \mathrm{ml}$ for corticosterone.

\section{Immunocytochemistry}

At $2 \mathrm{~h}$ after stress exposure, lesioned and sham-lesioned animals were deeply anaesthetized with an overdose of sodium pentobarbital $(200 \mathrm{mg} / \mathrm{kg})$ and transcardially perfused with $100 \mathrm{ml}$ of $0.9 \%$ saline followed by $100 \mathrm{ml}$ of $4 \%$ paraformaldehyde in $0.1 \mathrm{~mol} / 1$ phosphate-buffered solution (PBS, $\mathrm{pH} 7.4$ ). The $2 \mathrm{~h}$ time point represents the interval at which maximal c-Fos protein expression has been reported in acute stress paradigms (Viau and Sawchenko, 2002). Brains were then removed, post-fixed for $2 \mathrm{~h}$, and cryoprotected at $4^{\circ} \mathrm{C}$ overnight in $10 \%$ sucrose (in $0.1 \mathrm{M} \mathrm{PBS}, \mathrm{pH}$ 7.4). The coronal sections $(40 \mu \mathrm{m})$ were cut through the PVN using a Cryostat (Leica CM 1850, Leica-Microsystems, Nussloch, Germany) and collected in PBS. The sections were processed for c-Fos-like immunoreactivity as described previously (Smith and Day, 1993; Buller et al, 1999). Briefly, brain sections were incubated for $48 \mathrm{~h}$ in rabbit anti-Fos ( $1: 50.000$, Santa Cruz, CA, USA), followed by a $2 \mathrm{~h}$ incubation in a biotinylated donkey anti-rabbit $(1: 300$, Jackson ImmunoResearch, West Grove, PA, USA). Sections were then incubated for a further $2 \mathrm{~h}$ in a solution of avidinbiotin-horseradish peroxidase complex (ABC Vector Elite Kit, Burlingame, CA, USA) before being exposed to a nickel 


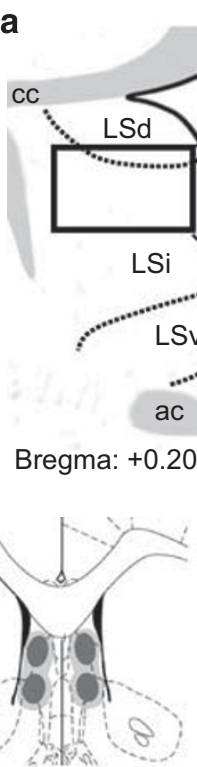

Bregma: $+1.20 \mathrm{~mm}$

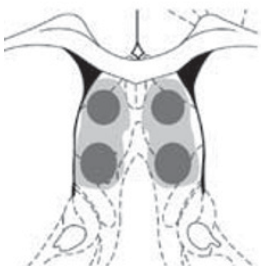

Bregma: $+0.20 \mathrm{~mm}$

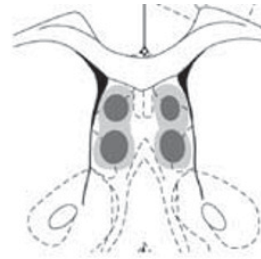

$+0.70 \mathrm{~mm}$

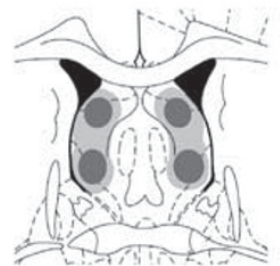

$-0.26 \mathrm{~mm}$

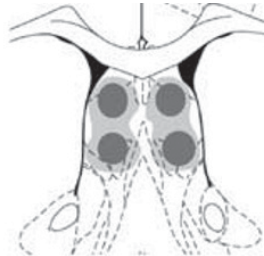

$+0.50 \mathrm{~mm}$

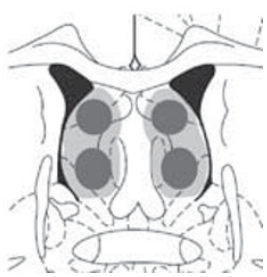

$-0.30 \mathrm{~mm}$

Figure I Placement and extent of bilateral LS lesions. (a) Schematic drawing of a coronal section illustrating the dorsal, intermediate, and ventral part of the LS (left panel), and photomicrographs showing cresyl-stained coronal sections of a lesioned and sham-lesioned control animal (right panel). LS lesions reduced the number of cells in the LS. Neuronal cell degeneration and cell loss was found in all subregions of the LS. (b) Schematic coronal sections of the rat brain adapted from the atlas of (Paxinos and Watson, 1998) illustrating rostrocaudal extension of lesions in the LS. The largest (bright gray) and smallest (dark gray) lesions are plotted at different levels through the LS. ac, anterior commissure; cc, corpus callosum; LSd, lateral septum dorsal; LSi, lateral septum intermediate; LSv, lateral septum ventral.

3,3-diaminobenzidine solution to allow visualization of the horseradish peroxidase activity. Cells containing a nuclear brown-black reaction product were considered as c-Fospositive cells. The reaction was terminated once an optimal contrast between specific cellular and nonspecific background labeling was reached. To minimize variations in immunolabeling, sections from each experimental group were processed simultaneously. Sections were then mounted on chrome-alum-subbed slides, dehydrated in alcohol, cleared in xylene, and cover slipped.

\section{Histology}

At the end of the experiments, animals were killed by an overdose of pentobarbital and their brains were removed. For histological verification of either the extension of LS lesions - on the basis of gliosis and neuronal cell loss (Figure 1) - or placement of microinjection cannulae and microdialysis probes (Figure 2), brains were sectioned using a cryostat and $20-40 \mu \mathrm{m}$ coronal sections were stained with

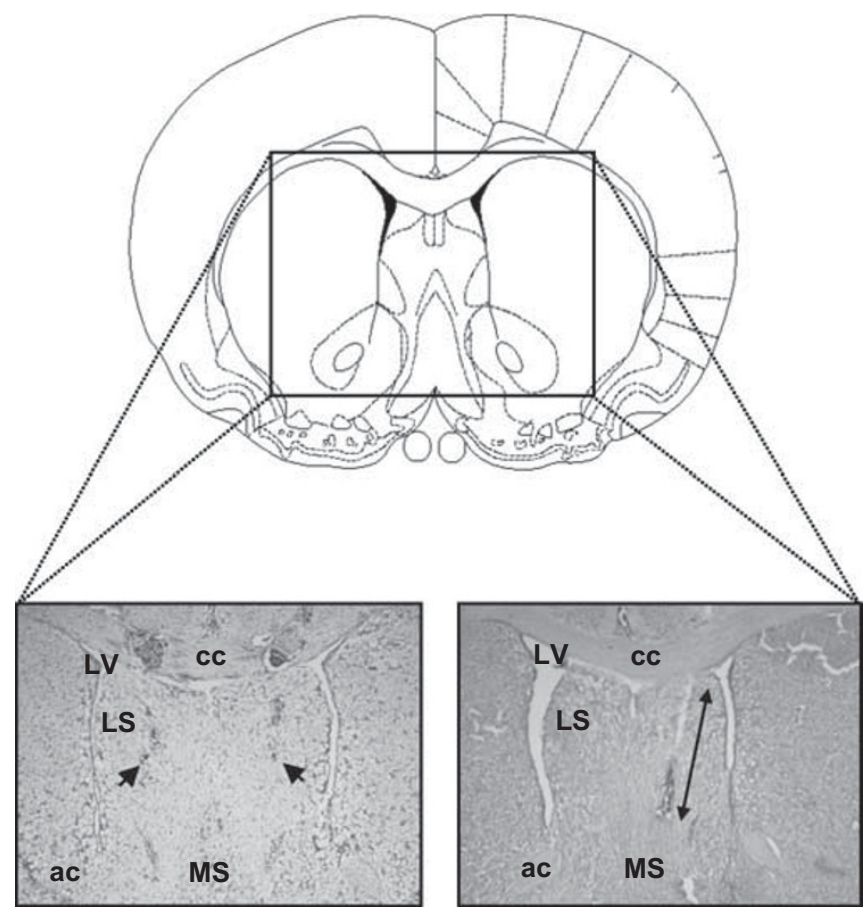

Figure 2 Schematic drawing and representative microphotographs of cresyl-stained coronal sections of the rat brain showing the localization of bilaterally implanted microinjection cannulae (left) and the active membrane tip of a microdialysis probe (right) within the LS. ac, anterior commissure; cc, corpus callosum; LV, lateral ventricle; MS, medial septum.

cresyl violet. Lesion verification and judgment of successful implantation of cannulae and probes into the LS was made before analyzing neuroendocrine and behavioral experiments.

\section{Statistics}

Experimental subjects were included in the statistical analysis only if the lesions, microinjection, or microdialysis cannulae were confirmed to be localized within the LS. Statistical analysis was performed using a computer software package (GB-Stat 6.0, Dynamic Microsystems, Silver Springs, USA). Plasma concentrations of ACTH and corticosterone were analyzed using a two-way ANOVA (treatment/lesion $\times$ time) with repeated measures on the last factor followed by appropriate post hoc analysis. Behavioral data and counts of c-Fos-positive nuclei within the PVN after stress exposure were analyzed using Student's two-tailed $t$-test, comparing lesioned or drug-treated animals with respective controls. Anatomical boundaries defining the subareas of interest within the PVN were evaluated with reference to morphological and cytoarchitectonic organization of the PVN (Swanson and Sawchenko, 1980). Data are presented as means \pm SEM. Statistical significance was accepted if $p<0.05$.

\section{RESULTS}

\section{Lesion placements}

Lesions were evaluated with reference to morphological and cytoarchitectonic organization of the LS (Alonso and Frotscher, 1989; Risold, 2004). Three subregions were of 

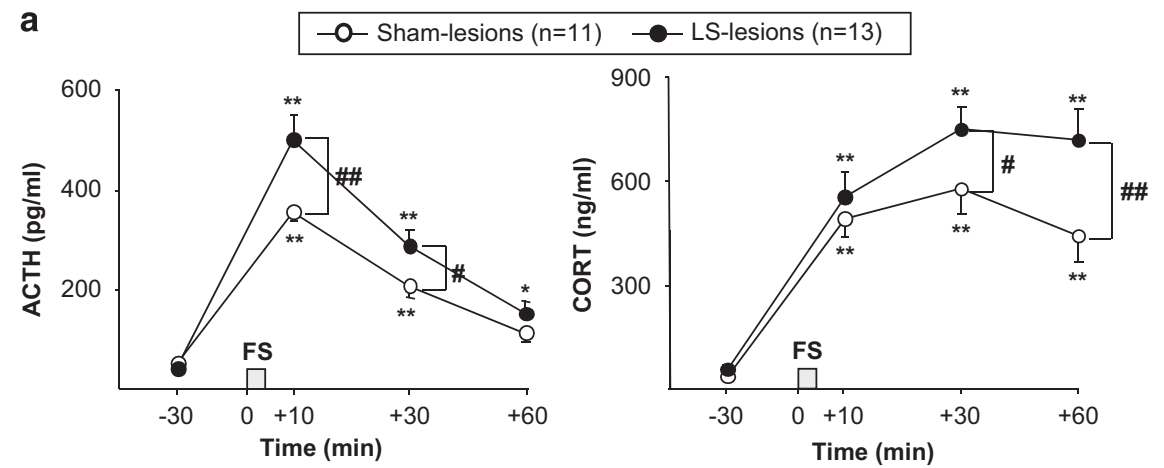

b
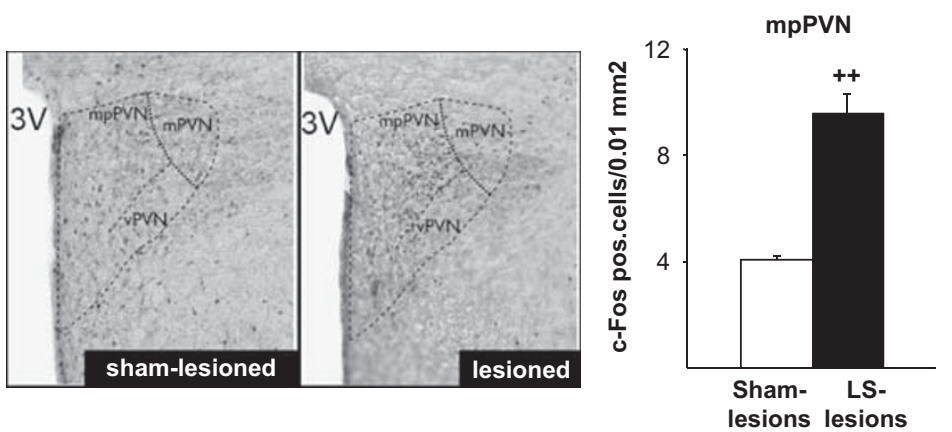

Figure 3 Effects of LS lesions on HPA axis responses to forced swimming. (a) Plasma ACTH (left) and corticosterone (CORT, right panel) responses to forced swimming (FS; $5 \mathrm{~min}, 20^{\circ} \mathrm{C}$, gray shaded bars). Swim stress caused a significant increase in plasma ACTH and corticosterone concentrations in both LS-lesioned and sham-lesioned animals. Compared with sham-lesioned animals, LS-lesioned animals showed a higher plasma ACTH and corticosterone levels during and after forced swimming but not under basal conditions. (b) Effects of LS lesions on swim stress-induced c-Fos expression in the mpPVN. Depicted are representative bright field photomicrographs (left panel) and c-Fos quantification presented as bar graphs (right panel) illustrating higher c-Fos expression in the mpPVN in lesioned animals compared with sham-lesioned controls. $3 \mathrm{~V}$, third ventricle; mPVN, magnocellular PVN; vPVN, ventral PVN; mpPVN, medial parvicellular PVN. Data expressed as means + SEM. ${ }^{*} p<0.05$, ${ }^{*} * p<0.01$ vs basal value; ${ }^{\#} p<0.05$, ${ }^{\# \#} p<0.01$ vs respective value in the sham-lesioned controls. ${ }^{++} p<0.00$ I vs sham-lesioned controls (Newman-Keuls post hoc test or Student's t-test).

primary interest: the dorsal, the intermediate, and the ventral part (Figure 1a, left panel). Lesion placement and extent was verified by light microscopic examination of cresyl violetstained sections showing substantial cell degeneration and cell loss resulting from ibotenic acid injections in lesioned compared with sham-lesioned animals (Figure 1a, right panel). Analysis of LS lesions indicated significant damage in all subregions as well as over the entire rostrocaudal extension of the LS (Figure 1b).

\section{Lesion effects on neuroendocrine stress response}

Exposure to forced swimming caused an increase in plasma ACTH and corticosterone levels in both LS-lesioned animals and sham-lesioned controls (Figure 3a). Statistical analysis of ACTH levels by two-way ANOVA revealed a significant effect of the main factors (lesion: $\mathrm{F}_{1,22}=8.56, p=0.0078$; time: $\left.\mathrm{F}_{3,66}=82.87, p<0.0001\right)$ as well as a significant interaction between main factors $\left(\mathrm{F}_{3,66}=3.24, p=0.0275\right)$. Post hoc analysis indicated significant differences of ACTH levels between lesioned animals and controls immediately after stress exposure with a higher ACTH response to forced swimming at $10(p<0.01)$ and $30 \mathrm{~min}(p<0.05)$ after onset of the stressor in lesioned animals compared with shamlesioned controls. In contrast, basal levels of ACTH did not vary as a function of lesion status (Figure $3 \mathrm{a},-30 \mathrm{~min}$ ).

Plasma corticosterone levels showed similar main effects (lesion: $\mathrm{F}_{1,22}=4.97, p=0.03$; time: $\mathrm{F}_{3,66}=69.89, p<0.0001$ ) and interaction of main factors $\left(\mathrm{F}_{3,66}=2.94, p=0.03\right)$.
Lesion status differentially affected the magnitude and longevity of the response, with lesioned animals showing higher and prolonged plasma corticosterone levels after forced swim stress than sham-lesioned controls. Basal levels of corticosterone were not different between groups.

\section{Lesion effects on stress-induced PVN activation}

Next we examined whether ablation of the LS is associated with an increased neuronal activity in the PVN, the apex of HPA axis regulation. Therefore, we compared the stressinduced expression of the immediate early gene product c-Fos in the PVN of LS-lesioned animals and controls. As shown in Figure $3 \mathrm{~b}$, sham-lesioned animals subjected to forced swim stress displayed moderate numbers of c-Fospositive cells in the PVN. Moreover, stress-induced c-Fos expression in the PVN, especially in the medial parvocellular part of the PVN (mpPVN), was considerably enhanced (by $140 \%$ ) in LS-lesioned animals compared with shamlesioned controls $(p<0.001)$.

\section{Lesion effects on behavioral stress response}

To determine the role of LS neurons on stress-related behavioral regulation, we monitored stress coping behavior during forced swimming in lesioned animals and controls. In this experiment, we found that LS lesions significantly affected the behavior of animals during forced swimming. As illustrated in Figure 4, LS-lesioned animals compared 


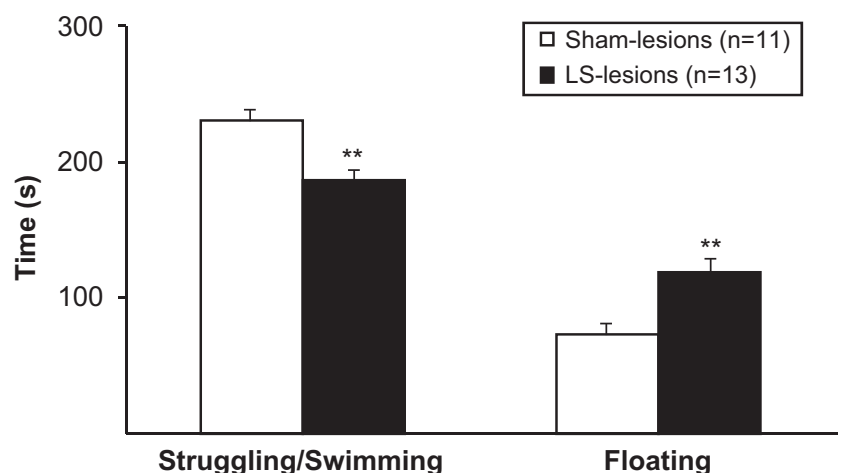

Figure 4 Effects of LS lesions on stress coping parameters during a 5-min forced swimming session as indicated by the time the animals spent struggling, swimming, and floating. Lesioned animals showed less active coping indicated by reduced time struggling and swimming and enhanced immobility (floating behavior) than sham-lesioned controls. Data are expressed as means +SEM. $* * * 0<0.001$ vs sham-lesioned controls (Student's t-test).

with sham-lesioned controls showed increased floating behavior $(p<0.001)$ and a decreased time spent with active coping, such as struggling and swimming $(p<0.001)$.

\section{Effects of intraseptal administration of selective corticosteroid receptor antagonists on stress responses}

In a further series of experiments, we aimed to clarify whether HPA inhibitory effects of the LS are mediated by septal glucocorticoid and/or mineralocorticoid receptors. Bilateral infusion of the selective glucocorticoid receptor antagonist mifepristone into the LS at different concentrations (20 and $100 \mathrm{ng}$ ) had no effect on HPA axis activity, as neither basal nor stress-induced ACTH (Figure 5a) or corticosterone levels (Figure $5 b$ ) differed between mifepristone- and aCSF-injected control animals. Moreover, intraseptal administration of the selective mineralocorticoid receptor antagonist RU-28318 had no effect on HPA axis activity. There was no difference either in basal ACTH (basal controls: $14.6 \pm 1.6 \mathrm{pg} / \mathrm{ml}$ ) or in corticosterone levels (basal controls: $60.3 \pm 15.2 \mathrm{ng} / \mathrm{ml}$ ) between vehicle-injected controls and RU-28318-treated rats. Also, the stress-induced ACTH and corticosterone levels did not differ between controls (peak levels ACTH: $337.4 \pm 86.3 \mathrm{pg} / \mathrm{ml}$; CORT: $759.5 \pm 64.2 \mathrm{ng} / \mathrm{ml}$ ) and antagonist treated animals (20 ng RU-28318: ACTH: $320.3 \pm 68.1 \mathrm{pg} / \mathrm{ml}$; CORT: $726.1 \pm 23.1$ ng/ml; 100 ng RU-28318: ACTH: $304.9 \pm 60.8 \mathrm{pg} / \mathrm{ml}$; CORT: $767.7 \pm 31.7 \mathrm{ng} / \mathrm{ml})$. However, septal glucocorticoid receptor blockade affected the stress coping behavior of animals during forced swimming. As illustrated in Figure 5c, mifepristone-injected animals showed increased struggling and swimming behavior $(p<0.01)$ and decreased time spent floating $(p<0.01)$ compared with aCSF-injected controls. In contrast, mineralocorticoid receptor antagonism did not influence stress coping behavior as floating (20 ng: $145.8 \pm$ 10.1 ; $100 \mathrm{ng}: 144.5 \pm 17.4)$ or struggling/swimming behavior of RU-28318-treated rats (20 ng: $153.2 \pm 10.2$; $100 \mathrm{ng}$ : $154.1 \pm 18.0)$ did not differ to that of vehicle-treated controls (floating: $137.6 \pm 8.6$; struggling/swimming: $161.8 \pm 8.5$ ).
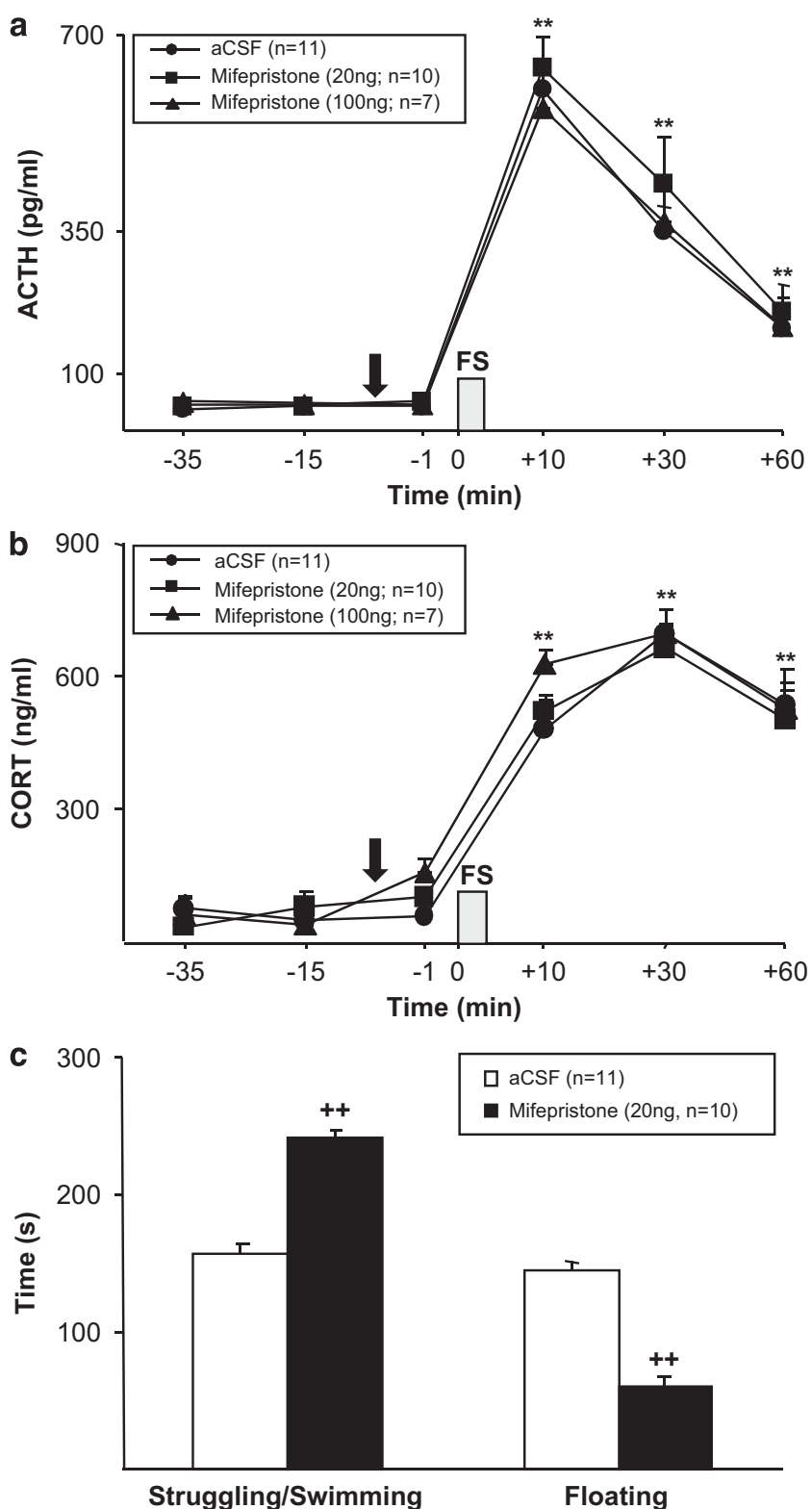

Figure 5 Effects of intraseptal administration of the glucocorticoid receptor antagonist mifepristone (20 or $100 \mathrm{ng} / \mathrm{side}$; black arrow) on neuroendocrine and behavioral stress response. Administration of mifepristone had no effect on either basal or stress-induced increase of plasma ACTH (a) or corticosterone (CORT, b) levels because there was no significant difference between mifepristone-treated animals and controls. (c) Mifepristone-injected animals showed an increased active coping style indicated by an enhancement of struggling and swimming and a reduction of floating behavior during the forced swim exposure. Data are expressed as means + SEM. ${ }^{* *} p<0.01$ vs basal values; ${ }^{++} p<0.001$ vs vehicle-treated controls (Newman-Keuls post hoc test or Student's $t$-test).

Effects of intraseptal administration of $5-\mathrm{HT}_{1 \mathrm{~A}}$ receptor ligands on stress responses

As shown in Figure 6, our data indicate significant differences in the plasma ACTH and corticosterone response to forced swimming between $5-\mathrm{HT}_{1 \mathrm{~A}}$ receptor agonist-treated animals and controls. Statistical analysis of ACTH levels by two-way ANOVA showed a significant effect of the factor time $\left(\mathrm{F}_{5,85}=89.57, p<0.0001\right)$ and a significant 

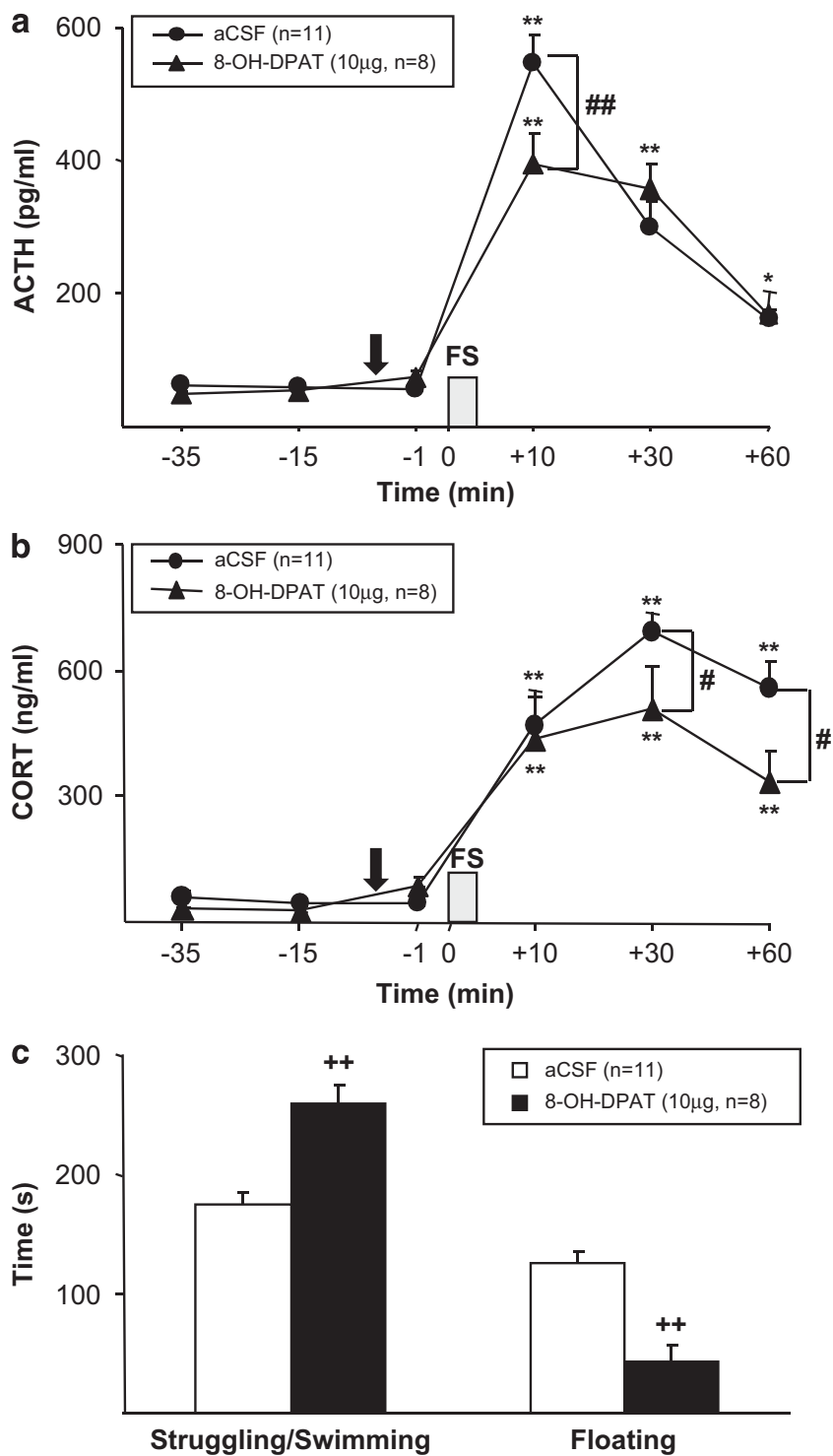

Figure 6 Effects of intraseptal administration of the 5-HT/A receptor agonist 8-OH-DPAT ( $10 \mu \mathrm{g} /$ side; black arrow) on neuroendocrine and behavioral stress response. Plasma ACTH (a) and corticosterone (CORT, b) responses to forced swimming were significantly attenuated by the 8-OH-DPAT treatment. However, basal levels did not differ between groups. (c) Rats injected with 8-OH-DPAT showed an increased active coping style indicated by an enhanced time the animals spent struggling and swimming, and reduced floating behavior during the forced swim exposure. Data are expressed as means +SEM. $* p<0.05$, $* * * 0.0$ I vs basal; ${ }^{\#} p<0.05,{ }^{\# \#} p<0.01$ vs respective value in the vehicle-treated controls; ${ }^{++} p<0.00$ I vs vehicle-treated controls (Newman-Keuls post hoc test or Student's t-test).

interaction between main factors $\left(\mathrm{F}_{5,85}=3.80, p=0.0037\right)$. Post hoc analysis revealed that the administration of the selective $5-\mathrm{HT}_{1 \mathrm{~A}}$ receptor agonist 8 -OH-DPAT locally into the LS resulted in a significant attenuation of swim stressinduced ACTH levels. The attenuation of the plasma ACTH response to forced swimming after intraseptal 8-OH-DPAT administration was evident only at the peak level at $10 \mathrm{~min}$ after stressor onset, whereas at $30 \mathrm{~min}$, at which ACTH levels were still significantly elevated, this difference was not observed. As shown in Figure 6b, all experimental groups
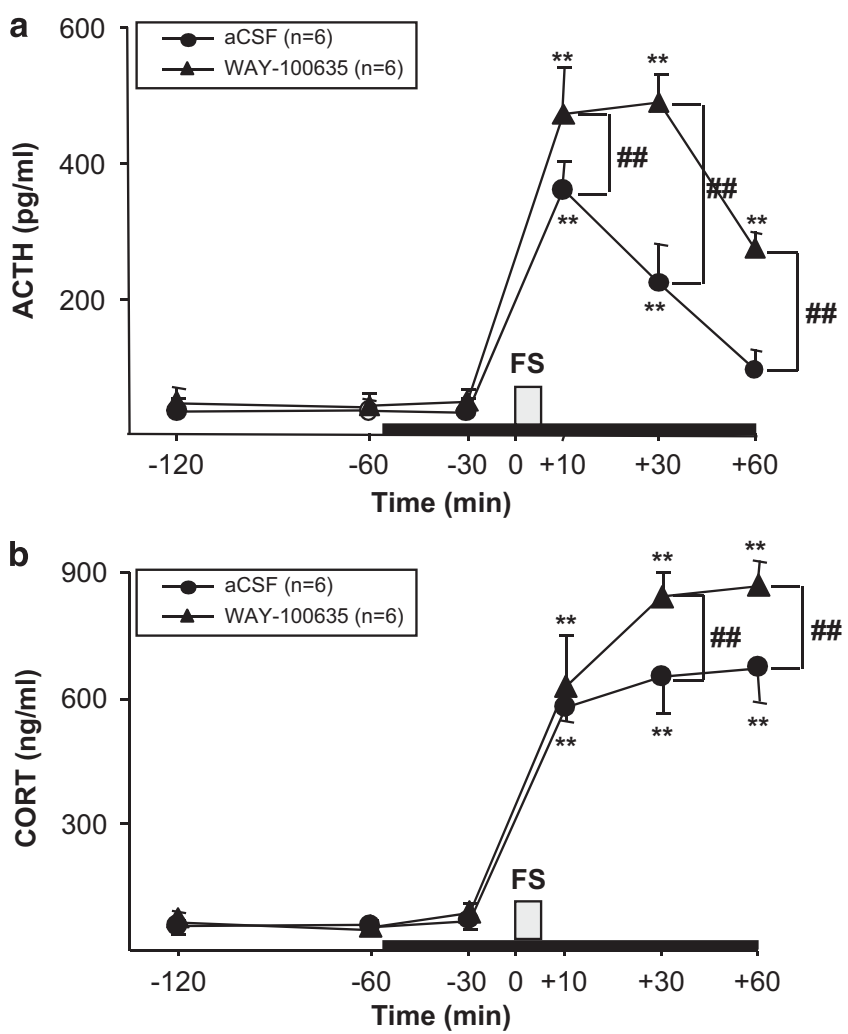

Figure 7 Effects of intraseptal infusion of the 5-HT/A receptor antagonist WAY-I00635 (I0 $\mathrm{MM}$ ) via retrodialysis (black bar) on basal and swim stress-induced ACTH (a) or corticosterone levels (CORT, b). Although basal ACTH and corticosterone levels did not differ between groups, the forced swim stress-induced ACTH and corticosterone levels were significantly higher in WAY-100635-treated animals compared with controls. Data are expressed as means + SEM. $* * *<0.0$ I vs basal values; $\# \#<0.01$ vs vehicle-treated controls (Newman-Keuls post hoc test).

exhibited increased plasma corticosterone levels in response to the $5 \mathrm{~min}$ forced swim stress exposure with peak levels at 30 min after stressor onset. Similarly to ACTH, 8-OH-DPAT significantly reduced the stress-induced rise of plasma corticosterone levels. Statistical analysis by two-way ANOVA revealed significant effects of the main factors (treatment: $\mathrm{F}_{1,17}=6.88, p=0.0178 ; \quad$ time: $\mathrm{F}_{5,85}=71.42$, $p<0.0001)$ and a significant interaction between main factors $\left(\mathrm{F}_{5,85}=3.05, p=0.0137\right)$. Notably, attenuated stressinduced corticosterone levels after intraseptal 8-OH-DPAT administration were observed only in the post-stress period with peak corticosterone levels at 30 and $60 \mathrm{~min}$ after stressor onset. In contrast, basal ACTH and corticosterone levels were not different between groups. Furthermore, intraseptal administration of 8-OH-DPAT significantly affected the behavior of the animals during forced swimming, indicated by increased active coping, such as struggling and swimming behavior $(p<0.01)$, and decreased time spent floating $(p<0.01)$ in agonist-treated animals compared with controls (Figure 6c).

Figure 7 illustrates the effects of intraseptal $5-\mathrm{HT}_{1 \mathrm{~A}}$ receptor blockade on basal and stress-induced ACTH and corticosterone levels. Infusion of the selective $5-\mathrm{HT}_{1 \mathrm{~A}}$ receptor antagonist WAY-100635 into the LS changed ACTH responses to forced swimming. Statistical analysis 
by two-way ANOVA showed a significant effect of the main factors (treatment: $F_{1,10}=11.46, p=0.0069$; time: $\left.\mathrm{F}_{5,50}=75.02, p<0.0001\right)$ as well as a significant interaction between main factors $\left(\mathrm{F}_{5,50}=7.38, p<0.0001\right)$. Post hoc analysis revealed that intraseptal administration of WAY100635 resulted in higher and prolonged swim stressinduced ACTH levels. Notably, this effect was long lasting and observable even at $60 \mathrm{~min}$ after stress exposure, because at this time point antagonist-treated animals, but not controls, showed elevated ACTH levels compared with basal. Similarly to ACTH, intraseptal WAY-100635 administration resulted in higher stress-induced corticosterone levels (notably at 30 and $60 \mathrm{~min}$ after stressor onset) than in controls with significant main factors (treatment: $\mathrm{F}_{1,10}=38.61, \quad p<0.0001 ;$ time: $\mathrm{F}_{5,50}=276.86, \quad p<0.0001$ ) as well as a significant interaction between main factors $\left(\mathrm{F}_{5,50}=4.41, p=0.002\right)$. In contrast, basal ACTH and corticosterone levels were not different between groups. Moreover, intraseptally administered WAY- 100635 did not affect the stress coping behavior of animals in the forced swim test as floating (113.8 \pm 15.9$)$ or struggling/swimming behavior $(153.2 \pm 10.2)$ of WAY-100635-treated rats did not differ to that of vehicle-treated controls (floating: $95.4 \pm 9.8$; struggling/swimming: $161.8 \pm 8.5$ ).

\section{DISCUSSION}

The results of the present study demonstrate an important role of the LS in the modulation of behavioral and neuroendocrine stress responses. Ablation of the LS was associated with disinhibited HPA axis stress responses indicated by enhanced plasma ACTH and corticosterone levels and an exaggerated c-Fos expression in the mpPVN. In contrast, lesions did not affect basal plasma hormone levels. The enhanced neuroendocrine stress response in LSlesioned animals was accompanied by alterations in the stress coping behavior during forced swimming, indicated by increased floating and reduced struggling/swimming behavior. In addition, we found that this HPA inhibitory mechanism of the LS is not mediated via septal corticosteroid receptors, as intraseptal glucocorticoid and mineralocorticoid receptor blockade failed to change HPA axis activity. However, we identified septal $5-\mathrm{HT}_{1 \mathrm{~A}}$ receptors to have an important role in this mechanism, as intraseptal $5-\mathrm{HT}_{1 \mathrm{~A}}$ receptor activation suppressed, whereas blockade of these receptors increased and prolonged stress-induced ACTH and corticosterone responses. Moreover, septal $5-\mathrm{HT}_{1 \mathrm{~A}}$ receptors also seem to be implicated in the modulation of behavioral stress coping as intraseptal administration of a $5-\mathrm{HT}_{1 \mathrm{~A}}$ receptor agonist increased active and decreased passive stress coping strategies.

\section{Role of LS neurons on neuroendocrine stress response}

In this work, we investigated the effects of selective lesions of the LS on plasma ACTH and corticosterone levels under basal and stress conditions. Notably, we could not observe any differences in basal ACTH or corticosterone levels between LS-lesioned animals and controls. Thus, our data are in contrast to previous findings showing higher corticosterone levels after ablation of the septum, suggest- ing a tonic inhibitory effect of septal neurons on HPA axis activity (Uhlir et al, 1974; Bouille and Bayle, 1975; Dobrakovova et al, 1982). Methodological differences might be a possible explanation of this discrepancy. As these early lesion studies used large electrolytic lesions, thereby destroying the whole septum and extensive portion of the fornix system (see Introduction), such kind of destruction can likely lead to a damage of putative inhibitory input to PVN neurons descending through the septal region. Thus, the results of these early studies are difficult to interpret with regard to the specific role of distinct subregions of the septum in HPA axis regulation. In line with our results are data from Herman et al (1996), showing no changes in basal corticosterone levels in rats with selective lesioning of the LS by using the neurotoxic agent ibotenic acid.

However, a novel finding in this study was that ACTH and corticosterone responses to swim stress increased after selective lesioning of LS neurons. In support of this, we observed increased neuronal activation (indicated by an enhancement of c-Fos-positive cells) in the mpPVN, the key region of HPA axis regulation that contains the main neuropeptidergic adrenocorticotropin secretagogues, such as CRF and arginine vasopressin (Antoni, 1986; Whitnall, 1993). Thus, our data suggest an inhibitory role of LS neurons on stress-induced HPA axis activity, and extend previous findings demonstrating higher corticosterone levels after electrolytic lesioning of the whole septum in rats (Brown et al, 1974; Usher et al, 1974; Dobrakovova et al, 1982; Seggie, 1987). In contrast to previous studies, in which only corticosterone levels were measured, our study provides information on HPA axis activity at different levels from hypothalamus, pituitary to adrenal level. Moreover, blood sampling through a jugular vein catheter as was carried out in our study offers the advantage of collecting sequential samples to monitor temporal changes in plasma stress hormones during and after stress exposure. Thus, in contrast to previous studies, wherein blood samples were collected by decapitation, our study provides some intraindividual time course information.

Next, we examined whether this HPA inhibitory mechanism of the LS is mediated by corticosteroid receptors that are highly expressed in the LS (see below). Previous studies have shown that stress-induced HPA axis activity is regulated by a glucocorticoid-driven feedback inhibition that is mediated, at least in part, by limbic forebrain structures (Herman et al, 2005). As both glucocorticoid and mineralocorticoid receptors are expressed in the LS (Arriza et al, 1988; Ahima and Harlan, 1990; Ahima et al, 1991; Cintra et al, 1994), this area might be a potential target for mediating glucocorticoid effects. However, neither injecting the selective glucocorticoid receptor antagonist mifepristone nor the selective mineralocorticoid receptor antagonist RU-28318 into the LS changed ACTH responses to forced swimming suggesting that this LS HPA inhibitory mechanism is independent of a glucocorticoid-mediated negative feedback mechanism. Thus, our data provide further evidence that the HPA axis can also be regulated by glucocorticoid-independent inhibition from neuronal sources. This is in line with findings from adrenalectomized animals that still can inhibit ACTH stress responses, although lacking glucocorticoid feedback signals (Jacobson et al, 1988). 


\section{Role of LS neurons on behavioral stress response}

In addition to HPA axis regulation, we found that the LS modulates stress coping behavior in the forced swim test, a widely used test to assess antidepressant properties of drugs. As LS-lesioned animals showed a more passive coping style, which is often interpreted as behavioral despair (Porsolt et al, 2001), our finding identified the LS as a key brain area, especially important in mediating active stress coping strategies. Thus, our data strengthen the suggestion that the septum, and especially the LS, belongs to a 'behavioral integration system' responsible for promoting the expression of relevant active behavioral responses in aversive and stressful situations (De Oca and Fanselow, 2004; Sheehan et al, 2004). Interestingly, previous studies have shown that LS lesions in rats produced an anxiogeniclike phenotype (Yadin et al, 1993). Accordingly, this effect was defined as 'septal rage syndrome' - representing a generalized disinhibition of fear (Brady and Nauta, 1953; Albert and Chew, 1980; Sheehan et al, 2004). Furthermore, septal damage has been found to be correlated with an increase in the expression of defensive behaviors, which is suggestive of an increase in fear (Sparks and LeDoux, 1995). However, different LS lesion studies suggest some anxiolytic-like effects in the elevated plus-maze and shock-probe burying test after LS ablation (Pesold and Treit, 1992; Menard and Treit, 1996). Thus, the exact role of the LS in modulation of anxiety and emotion-related behaviors is still not fully understood. Methodological differences, such as extent of lesions and ways of application, might be responsible for the disparity between findings. It might be speculated that even subregions of the LS mediate different and distinct behavioral functions and therefore, it depends on the exact position and extent of lesions which effects are finally produced.

Interestingly, previous studies point to a critical role of the LS in mediating behavioral symptoms of depression. For instance, in the learned helplessness paradigm in rats, a widely used animal model of depression, it has been shown that helpless animals show lower stress-induced neuronal activation within the LS than controls (Steciuk et al, 1999). However, stress-resistant rats, who received the same inescapable shock but did not become helpless, showed no reduction in septal activity, indicating that a normal functioning of the LS is required for effective coping responses to inescapable stress. Conversely, substantial evidence suggests that antidepressants ameliorate the behavioral manifestations of depression by restoring the neuronal activity in the LS (Contreras et al, 1989, 1990, 2001; Lino-de-Oliveira et al, 2001; Muigg et al, 2007). Therefore, we injected mifepristone, a selective glucocorticoid receptor antagonist with anxiolytic and antidepressant properties (De Kloet et al, 1988; Korte et al, 1995; DeBattista and Belanoff, 2006; Schatzberg and Lindley, 2008; Wulsin et al, 2010), locally into the LS and measured behavioral stress coping behavior in the forced swim test. Notably, we found that local administration of mifepristone into the LS increased active coping and reduced floating behavior indicating an antidepressant-like effect. This behavioral effect seems to be mediated by glucocorticoid receptors, as intraseptal administration of a mineralocorticoid receptor antagonist had no effect. Thus, our data extend previous findings demonstrating that intraseptal injection of mifepristone normalizes the anxiogenic response in the elevated plus-maze test induced by either previous social defeat or systemic corticosterone administration (Calfa et al, 2006). However, mifepristone is not an ideal glucocorticoid receptor antagonist, because it has also some affinity to progesterone receptors. As progesterone receptors are also expressed in the LS (MacLusky and McEwen, 1980; Sar and Parikh, 1986), and intraseptally administered progesterone has been shown to influence forced swim behavior (EstradaCamarena et al, 2002), it is possible that these receptors are involved in the mediation of the behavioral effects of mifepristone. Further studies with more specific ligands for the glucocorticoid receptor are required to exclude this possibility.

\section{Involvement of septal $5-\mathrm{HT}_{1 \mathrm{~A}}$ receptors in stress responses}

After identifying a stress inhibitory role of the LS, we wanted to gain insight into the neurochemistry involved this effect. Previous studies suggest that the septal 5-HT system has an important role in mediating behavioral and physiological responses to emotionally significant events. Both a dense serotonergic innervation of the LS from the raphe nuclei (Köhler et al, 1982) and various 5-HT receptors primarily of the $5-\mathrm{HT}_{1 \mathrm{~A}}$ subtype are highly expressed in the LS (Kia et al, 1996; Lanfumey and Hamon, 2000). Therefore, we bidirectonally modulated septal $5-\mathrm{HT}_{1 \mathrm{~A}}$ receptors by the administration of a selective $5-\mathrm{HT}_{1 \mathrm{~A}}$ receptor agonist and antagonist into the LS, and examined the role of this receptor on neuroendocrine and behavioral stress responses. We found a suppression of the stress-induced $\mathrm{ACTH}$ and corticosterone levels after 5-HT $1 \mathrm{~A}$ receptor agonist administration and an increased and prolonged ACTH and corticosterone response after $5-\mathrm{HT}_{1 \mathrm{~A}}$ receptor blockade. Thus, our data suggest an inhibitory role of endogenous 5-HT within the LS on stress-induced HPA axis activation via intraseptal $5-\mathrm{HT}_{1 \mathrm{~A}}$ receptors. Notably, blockade of septal $5-\mathrm{HT}_{1 \mathrm{~A}}$ receptors by WAY-100635 mimics lesion effects, whereas activation of these receptors facilitates the inhibitory role of the LS. The exact mechanism, however, mediating this inhibitory effect to the PVN remains unclear. It was shown previously that LS $5-\mathrm{HT}_{1 \mathrm{~A}}$ receptors were located primarily on calbindin-positive neurons, indicative for septal GABAergic interneurons (Aznar et al, 2003; Lüttgen et al, 2005). Moreover, electrophysiological experiments have established that septal $5-\mathrm{HT}_{1 \mathrm{~A}}$ receptor activation causes neuronal hyperpolarization (Joëls et al, 1987; Van den Hooff and Galvan, 1992). Thus, it is conceivable that a reduced 5-HT function in the LS either during psychological stress exposure (Kirby et al, 1995; Ebner et al, 2008) or after 5- $\mathrm{HT}_{1 \mathrm{~A}}$ receptor blockade is associated with an enhanced intraseptal inhibitory function (presumably via GABAergic interneurons). As a major part of LS output neurons are GABAergic (Gallagher et al, 1995; Risold and Swanson, 1997) and given that several LS projections to the PVN are GABAergic, this GABA-to-GABA pathway would result in disinhibition of HPA axis stress responses. However, it is also conceivable that increased HPA axis stress responses are mediated not directly through GABAergic efferents to the PVN but 
indirectly through glutamatergic projections to inhibitory $\mathrm{PVN}$ projecting regions, including the peri-PVN region (Herman et al, 2004; Cullinan et al, 2008). Both scenarios would lead to enhanced stress hormone levels during forced swimming resulting from a decreased inhibitory action of the LS on the PVN. Further studies using tract tracing methods combined with immunohistochemical techniques (eg, c-Fos, GABA) should clarify the exact pathways and mechanisms underlying this septal HPA axis regulatory mechanism.

Interestingly, the suppression of stress-induced ACTH and corticosterone levels after intraseptal $5-\mathrm{HT}_{1 \mathrm{~A}}$ receptor activation was accompanied by behavioral alterations during forced swimming, including reduction of immobility and an increase in active coping (eg, struggling and swimming). Thus, our data confirm earlier studies also demonstrating antidepressant-like effects after intraseptal 8-OH-DPAT administration in the classical forced swim test (Schreiber and De Vry, 1993) and learned helplessness model (Martin et al, 1990). In the present study, we used a modified version of the forced swim test to assess the reactivity of the rodent to the novel stress environment without any potential confounds of learning/memory processes associated with the pretest session performed in the traditional test. These modifications make the test more sensitive for serotonergic antidepressant drugs, such as SSRIs (Detke et al, 1995; Cryan et al, 2005). Indeed, preliminary data from our laboratory shows a reduction of floating behavior and an enhancement of struggling behavior in our modified forced swim test after intraseptal administration of citalopram (Ebner $\mathrm{K}$ et al, unpublished data). Interestingly, we could not observe any behavioral changes during the forced swim session in animals that were intraseptally infused with the selective $5-\mathrm{HT}_{1 \mathrm{~A}}$ receptor antagonist WAY-100635. This might be surprising in respect to the observed effects of WAY-100635 in modulating the neuroendocrine stress response. However, although the reason for the behavioral ineffectiveness is currently unknown, it could be related to the low endogenous 5-HT tonus in the LS during forced swimming (Kirby et al, 1995; Ebner et al, 2008). Therefore, it is conceivable that under those conditions the endogenous 5-HT level is not sufficient for significant behavioral effects after $5-\mathrm{HT}_{1 \mathrm{~A}}$ receptor blockade. Indeed, the lack of a behavioral effect in the forced swim test after $5-\mathrm{HT}_{1 \mathrm{~A}}$ receptor blockade was also reported after systemic administration (De Vry, 1995; De Vry et al, 2004; Cryan et al, 2005).

Taken together, our results show that the LS has an important role in promoting a HPA axis inhibitory mechanism and active coping strategies during stress exposure. Furthermore, we found that this HPA inhibitory mechanism of the LS acts independent from glucocorticoidmediated negative feedback mechanisms. However, our data indicate a critical role of septal $5-\mathrm{HT}_{1 \mathrm{~A}}$ receptors in mediating stress-preventing actions of the LS as activation of septal $5-\mathrm{HT}_{1 \mathrm{~A}}$ receptors inhibits neuroendocrine and facilitates behavioral stress responses. Thus, our study supports a model, in which enhanced activity of LS neurons is required for effective stress coping responses, which provides improved protection from the deleterious effects of exaggerated psychological stress exposure.

\section{DISCLOSURE}

The author(s) declare that, except for income received from my primary employer, no financial support or compensation has been received from any individual or corporate entity over the past 3 years for research or professional service, and there are no personal financial holdings that could be perceived as constituting a potential conflict of interest.

\section{ACKNOWLEDGEMENTS}

This work was supported by the Austrian Science Fund FWF (KE).

\section{REFERENCES}

Ahima R, Krozowski Z, Harlan R (1991). Type I corticosteroid receptor-like immunoreactivity in the rat CNS: distribution and regulation by corticosteroids. J Comp Neurol 313: 522-538.

Ahima RS, Harlan RE (1990). Charting of type II glucocorticoid receptor-like immunoreactivity in the rat central nervous system. Neuroscience 39: 579-604.

Albert DJ, Chew GL (1980). The septal forebrain and the inhibitory modulation of attack and defense in the rat. A review. Behav Neural Biol 30: 357-388.

Alonso JR, Frotscher M (1989). Organization of the septal region in the rat brain: a Golgi/EM study of lateral septal neurons. J Comp Neurol 286: 472-487.

Antoni FA (1986). Hypothalamic control of adrenocorticotropin secretion: advances since the discovery of 41-residue corticotropin-releasing factor. Endocr Rev 7: 351-378.

Arriza JL, Simerly RB, Swanson LW, Evans RM (1988). The neuronal mineralocorticoid receptor as a mediator of glucocorticoid response. Neuron 1: 887-900.

Aznar S, Qian Z, Shah R, Rahbek B, Knudsen GM (2003). The 5-HT1A serotonin receptor is located on calbindin- and parvalbumin-containing neurons in the rat brain. Brain Res 959: 58-67.

Bouille C, Bayle JD (1975). Influence of septal nuclei on basal pituitary-adrenocortical function in birds. Neuroendocrinology 18: 281-289.

Bourne JA (2003). Intracerebral microdialysis: 30 years as a tool for the neuroscientist. Clin Exp Pharmacol Physiol 30: 16-24.

Brady JV, Nauta WJ (1953). Subcortical mechanisms in emotional behavior: affective changes following septal forebrain lesions in the albino rat. J Comp Physiol Psychol 46: 339-346.

Brown GM, Uhlir IV, Seggie J, Schally AV, Kastin AJ (1974). Effect of septal lesions on plasma levels of MSH, corticosterone, GH and prolactin before and after exposure to novel environment: role of MSH in the septal syndrome. Endocrinology 94: 593-597.

Buller KM, Smith DW, Day TA (1999). Differential recruitment of hypothalamic neuroendocrine and ventrolateral medulla catecholamine cells by non-hypotensive and hypotensive hemorrhages. Brain Res 834: 42-54.

Calfa G, Volosin M, Molina VA (2006). Glucocorticoid receptors in lateral septum are involved in the modulation of the emotional sequelae induced by social defeat. Behav Brain Res 172: 324-332.

Calvo N, Volosin M (2001). Glucocorticoid and mineralocorticoid receptors are involved in the facilitation of anxiety-like response induced by restraint. Neuroendocrinology 73: 261-271.

Cintra A, Zoli M, Rosen L, Agnati LF, Okret S, Wikstrom AC et al (1994). Mapping and computer assisted morphometry and microdensitometry of glucocorticoid receptor immunoreactive neurons and glial cells in the rat central nervous system. Neuroscience 62: 843-897. 
Contreras CM, Alcala-Herrera V, Marvan ML (1989). Action of antidepressants on the septal nuclei of the rat. Physiol Behav 46: 793-798.

Contreras CM, Marvan ML, Alcala-Herrera V, Guzman-Saenz MA (1990). Chronic clomipramine increases firing rate in lateral septal nuclei of the rat. Physiol Behav 48: 551-554.

Contreras CM, Rodriguez-Landa JF, Gutierrez-Garcia AG, Bernal-Morales B (2001). The lowest effective dose of fluoxetine in the forced swim test significantly affects the firing rate of lateral septal nucleus neurones in the rat. J Psychopharmacol 15: 231-236.

Cryan JF, Valentino RJ, Lucki I (2005). Assessing substrates underlying the behavioral effects of antidepressants using the modified rat forced swimming test. Neurosci Biobehav Rev 29: 547-569.

Cullinan WE, Ziegler DR, Herman JP (2008). Functional role of local GABAergic influences on the HPA axis. Brain Struct Funct 213: 63-72.

De Kloet ER, De Kock S, Schild V, Veldhuis HD (1988). Antiglucocorticoid RU 38486 attenuates retention of a behaviour and disinhibits the hypothalamic-pituitary adrenal axis at different brain sites. Neuroendocrinology 47: 109-115.

De Kloet ER, Joels M, Holsboer F (2005). Stress and the brain: from adaptation to disease. Nat Rev Neurosci 6: 463-475.

De Kloet ER, Vreugdenhil E, Oitzl MS, Joels M (1998). Brain corticosteroid receptor balance in health and disease. Endocr Rev 19: $269-301$.

De Oca BM, Fanselow MS (2004). Amygdala and periaqueductal gray lesions only partially attenuate unconditional defensive responses in rats exposed to a cat. Integr Physiol Behav Sci 39: 318-333.

De Vry J (1995). 5-HT1A receptor agonists: recent developments and controversial issues. Psychopharmacology 121: $1-26$.

De Vry J, Schreiber R, Melon C, Dalmus M, Jentzsch KR (2004). 5-HT1A receptors are differentially involved in the anxiolyticand antidepressant-like effects of 8-OH-DPAT and fluoxetine in the rat. Eur Neuropsychopharmacol 14: 487-495.

DeBattista C, Belanoff J (2006). The use of mifepristone in the treatment of neuropsychiatric disorders. Trends Endocrinol Metab 17: 117-121.

Detke MJ, Rickels M, Lucki I (1995). Active behaviors in the rat forced swimming test differentially produced by serotonergic and noradrenergic antidepressants. Psychopharmacology 121: 66-72.

Dobrakovova M, Kvetnansky R, Torda T, Murgas K (1982). Changes of plasma and adrenal catecholamines and corticosterone in stressed rats with septal lesions. Physiol Behav 29: 41-45.

Ebner K, Rupniak NM, Saria A, Singewald N (2004). Substance P in the medial amygdala: emotional stress-sensitive release and modulation of anxiety-related behavior in rats. Proc Natl Acad Sci USA 101: 4280-4285.

Ebner K, Singewald GM, Whittle N, Ferraguti F, Singewald N (2008). Neurokinin 1 receptor antagonism promotes active stress coping via enhanced septal 5-HT transmission. Neuropsychopharmacology 33: 1929-1941.

Ebner K, Wotjak CT, Landgraf R, Engelmann M (2005). Neuroendocrine and behavioral response to social confrontation: residents $v s$ intruders, active $v s$ passive coping styles. Horm Behav 47: 14-21.

Estrada-Camarena E, Contreras CM, Saavedra M, Luna-Baltazar I, López-Rubalcava C (2002). Participation of the lateral septal nuclei (LSN) in the antidepressant-like actions of progesterone in the forced swimming test (FST). Behav Brain Res 134: $175-183$.

Gallagher JP, Zheng F, Hasuo H, Shinnick-Gallagher P (1995). Activities of neurons within the rat dorsolateral septal nucleus (DLSN). Prog Neurobiol 45: 373-395.
Gesing A, Bilang-Bleuel A, Droste SK, Linthorst AC, Holsboer F, Reul JM (2001). Psychological stress increases hippocampal mineralocorticoid receptor levels: involvement of corticotropinreleasing hormone. J Neurosci 21: 4822-4829.

Herman JP, Figueiredo H, Mueller NK, Ulrich-Lai Y, Ostrander MM, Choi DC et al (2003). Central mechanisms of stress integration: hierarchical circuitry controlling hypothalamo-pituitaryadrenocortical responsiveness. Front Neuroendocrinol 24: $151-180$.

Herman JP, Mueller NK, Figueiredo H (2004). Role of GABA and glutamate circuitry in hypothalamo-pituitary-adrenocortical stress integration. Ann N Y Acad Sci 1018: 35-45.

Herman JP, Ostrander MM, Mueller NK, Figueiredo H (2005). Limbic system mechanisms of stress regulation: Hypothalamopituitary-adrenocortical axis. Prog Neuropsychopharmacol Biol Psychiatry 29: 1201-1213.

Herman JP, Prewitt CM, Cullinan WE (1996). Neuronal circuit regulation of the hypothalamo-pituitary-adrenocortical stress axis. Crit Rev Neurobiol 10: 371-394.

Jacobson L, Akana SF, Cascio CS, Shinsako J, Dallman MF (1988). Circadian variations in plasma corticosterone permit normal termination of adrenocorticotropin responses to stress. Endocrinology 122: 1343-1348.

Joels M, Shinnick-Gallagher P, Gallagher JP (1987). Effect of serotonin and serotonin analogues on passive membrane properties of lateral septal neurons in vitro. Brain Res 417: 99-107.

Keller-Wood ME, Dallman MF (1984). Corticosteroid inhibition of ACTH secretion. Endocr Rev 5: 1-24.

Kia HK, Miquel MC, Brisorgueil MJ, Daval G, Riad M, El Mestikawy S et al (1996). Immunocytochemical localization of serotonin1A receptors in the rat central nervous system. J Comp Neurol 365: 289-305.

Kirby LG, Allen AR, Lucki I (1995). Regional differences in the effects of forced swimming on extracellular levels of 5-hydroxytryptamine and 5-hydroxyindoleacetic acid. Brain Res 682: 189-196.

Köhler C, Chan-Palay V, Steinbusch H (1982). The distribution and origin of serotonin-containing fibers in the septal area: a combined immunohistochemical and fluorescent retrograde tracing study in the rat. J Comp Neurol 209: 91-111.

Korte SM, de Boer SF, de Kloet ER, Bohus B (1995). Anxiolytic-like effects of selective mineralocorticoid and glucocorticoid antagonists on fear-enhanced behavior in the elevated plus-maze. Psychoneuroendocrinology 20: 385-394.

Krishnan V, Nestler EJ (2008). The molecular neurobiology of depression. Nature 455: 894-902.

Lanfumey L, Hamon M (2000). Central 5-HT(1A) receptors: regional distribution and functional characteristics. Nucl Med Biol 27: 429-435.

Lino-de-Oliveira C, Sales AJ, Del Bel EA, Silveira MC, Guimaraes FS (2001). Effects of acute and chronic fluoxetine treatments on restraint stress-induced Fos expression. Brain Res Bull 55: 747-754

Lüttgen M, Ogren SO, Meister B (2005). 5-HT1A receptor mRNA and immunoreactivity in the rat medial septum/diagonal band of Broca-relationships to GABAergic and cholinergic neurons. J Chem Neuroanat 29: 93-111.

MacLusky NJ, McEwen BS (1980). Progestin receptors in rat brain: distribution and properties of cytoplasmic progestin-binding sites. Endocrinology 106: 192-202.

Martin P, Beninger RJ, Hamon M, Puech AJ (1990). Antidepressant-like action of 8-OH-DPAT, a 5-HT1A agonist, in the learned helplessness paradigm: evidence for a postsynaptic mechanism. Behav Brain Res 38: 135-144.

McEwen BS (2007). Physiology and neurobiology of stress and adaptation: central role of the brain. Physiol Rev 87: 873-904. 
Menard J, Treit D (1996). Lateral and medial septal lesions reduce anxiety in the plus-maze and probe-burying tests. Physiol Behav 60: 845-853.

Morimoto M, Morita N, Ozawa H, Yokoyama K, Kawata M (1996). Distribution of glucocorticoid receptor immunoreactivity and mRNA in the rat brain: an immunohistochemical and in situ hybridization study. Neurosci Res 26: 235-269.

Muigg P, Hoelzl U, Palfrader K, Neumann I, Wigger A, Landgraf R et al (2007). Altered brain activation pattern associated with drug-induced attenuation of enhanced depression-like behavior in rats bred for high anxiety. Biol Psychiatry 61: 782-796.

Patel PD, Lopez JF, Lyons DM, Burke S, Wallace M, Schatzberg AF (2000). Glucocorticoid and mineralocorticoid receptor mRNA expression in squirrel monkey brain. J Psychiatr Res 34: 383-392.

Paxinos G, Watson C (1998). The Rat Brain in Stereotaxic Coordinates. Academic Press: New York.

Pesold C, Treit D (1992). Excitotoxic lesions of the septum produce anxiolytic effects in the elevated plus-maze and the shock-probe burying tests. Physiol Behav 52: 37-47.

Porsolt RD, Brossard G, Hautbois C, Roux S (2001). Rodent models of depression: forced swimming and tail suspension behavioral despair tests in rats and mice. Curr Protoc Neurosci Chapter 8: Unit 8 10A.

Ratka A, Sutanto W, Bloemers M, de Kloet ER (1989). On the role of brain mineralocorticoid (type I) and glucocorticoid (type II) receptors in neuroendocrine regulation. Neuroendocrinology 50: 117-123.

Risold PY (2004). The septal region. In: Paxinos G, (ed). The Rat Nervous System. Elsevier Academic Press: San Diego, pp 605-632.

Risold PY, Swanson LW (1997). Connections of the rat lateral septal complex. Brain Res Brain Res Rev 24: 115-195.

Sar M, Parikh I (1986). Immunohistochemical localization of estrogen receptor in rat brain, pituitary and uterus with monoclonal antibodies. J Steroid Biochem 24: 497-503.

Schatzberg AF, Lindley S (2008). Glucocorticoid antagonists in neuropsychiatric [corrected] disorders. Eur J Pharmacol 583: 358-364.

Schreiber R, De Vry J (1993). Neuroanatomical basis for the antidepressant-like effects of the 5-HT(1A) receptor agonists 8-OH-DPAT and ipsapirone in the rat forced swimming test. Behav Pharmacol 4: 625-636.

Seggie J (1987). Differential responsivity of corticosterone and prolactin to stress following lesions of the septum or amygdala: implications for psychoneuroendocrinology. Prog Neuropsychopharmacol Biol Psychiatry 11: 315-324.

Seggie J, Brown GM (1971). Septal lesions and resting adrenal function. A possible explanation of conflicting findings. Neuroendocrinology 8: 367-372.

Seggie J, Uhlir I, Brown GM (1974). Adrenal stress responses following septal lesions in the rat. Neuroendocrinology 16: 225-236.

Sheehan TP, Chambers RA, Russell DS (2004). Regulation of affect by the lateral septum: implications for neuropsychiatry. Brain Res Brain Res Rev 46: 71-117.

Smith DW, Day TA (1993). Neurochemical identification of fospositive neurons using two-colour immunoperoxidase staining. J Neurosci Methods 47: 73-83.

Sparks PD, LeDoux JE (1995). Septal lesions potentiate freezing behavior to contextual but not to phasic conditioned stimuli in rats. Behav Neurosci 109: 184-188.

Steciuk M, Kram M, Kramer GL, Petty F (1999). Decrease in stressinduced c-Fos-like immunoreactivity in the lateral septal nucleus of learned helpless rats. Brain Res 822: 256-259.

Swanson LW, Sawchenko PE (1980). Paraventricular nucleus: a site for the integration of neuroendocrine and autonomic mechanisms. Neuroendocrinology 31: 410-417.

Uhlir I, Seggie J, Brown GM (1974). The effect of septal lesions on the threshold of adrenal stress response. Neuroendocrinology 14: 351-355.

Usher DR, Lieblich I, Siegel RA (1974). Pituitary adrenal function after small and large lesions in the lateral septal area in fooddeprived rats. Neuroendocrinology 16: 156-164.

Van den Hooff P, Galvan M (1992). Actions of 5-hydroxytryptamine and 5-HT1A receptor ligands on rat dorso-lateral septal neurones in vitro. Br J Pharmacol 106: 893-899.

Van Haarst AD, Oitzl MS, de Kloet ER (1997). Facilitation of feedback inhibition through blockade of glucocorticoid receptors in the hippocampus. Neurochem Res 22: 1323-1328.

Viau V, Sawchenko PE (2002). Hypophysiotropic neurons of the paraventricular nucleus respond in spatially, temporally, and phenotypically differentiated manners to acute $v s$ repeated restraint stress: rapid publication. J Comp Neurol 445: 293-307.

Whitnall MH (1993). Regulation of the hypothalamic corticotropin-releasing hormone neurosecretory system. Prog Neurobiol 40: 573-629.

Wulsin AC, Herman JP, Solomon MB (2010). Mifepristone decreases depression-like behavior and modulates neuroendocrine and central hypothalamic-pituitary-adrenocortical axis responsiveness to stress. Psychoneuroendocrinology 35: 1100-1112.

Yadin E, Thomas E, Grishkat HL, Strickland CE (1993). The role of the lateral septum in anxiolysis. Physiol Behav 53: 1077-1083.

(c)

SOMERTHWHSTEE Works 3.0 Unported License. To view a copy of this license, visit http://creativecommons.org/ licenses/by-nc-nd/3.0/ 